This item was submitted to Loughborough's Research Repository by the author.

Items in Figshare are protected by copyright, with all rights reserved, unless otherwise indicated.

\title{
Cherchez la femme: Looking for lesbian femininities in literature, 1850-1928
}

PLEASE CITE THE PUBLISHED VERSION

https://www.palgrave.com/gp/book/9783319967691\#aboutBook

\section{PUBLISHER}

Palgrave Macmillan

\section{VERSION}

AM (Accepted Manuscript)

\section{PUBLISHER STATEMENT}

This book chapter was published in the book Intersections of Gender, Class, and Race in the Long Nineteenth Century and Beyond. The definitive published version is available at http://doi.org/10.1007/978-3-319-96770-7

\section{LICENCE}

CC BY-NC-ND 4.0

\section{REPOSITORY RECORD}

Parker, Sarah. 2019. "Cherchez La Femme: Looking for Lesbian Femininities in Literature, 1850-1928". Loughborough University. https://hdl.handle.net/2134/34030. 
Cherchez La Femme: Looking for Lesbian Femininities in Literature, 1850-1928

\section{Sarah Parker}

\section{Introduction: Cherchez la femme}

The majority of scholarship on lesbian representation in literature of the late-Victorian and early twentieth-century has tended to focus on gender inversion, concentrating on women that exhibit traits associated with masculinity rather than femininity. Such research draws on the theories of sexual inversion developed by sexologists such as Havelock Ellis and Richard von Kraft-Ebing, who wrote of the female invert's "masculine soul, heaving in the female bosom."1 Such sexological theories understood homosexual attraction as arising primarily from internalised gender dysphoria. Theories of sexual inversion can also be linked to the reactionary fears levelled at the New Woman and the male dandy as "twin monsters of degenerate age," blurring the boundaries of gender at the fin de siècle through such threateningly unconventional activities as smoking, bicycling and wearing bloomers on the one hand, and flaunting dandyism, cosmetics and green carnations on the other. ${ }^{2}$ Such "sexual anarchy" eventually became firmly linked to homosexuality through the very public trials of Oscar Wilde in 1895 and Radclyffe Hall in $1928 .^{3}$

Wilde and Hall's trials offer specific case studies supporting Foucault's contention that rather than "a temporary aberration" the "homosexual was now a species.”4 As Alan Sinfield has argued in relation to Wilde, through the huge public exposure in such trials, these figures became concretely identifiable as discreet homosexual "types." 5 Both Wilde and Hall’s image was interpreted after the fact as 
evidence of the ultimate homosexual type. For example, whereas before the trial, Wilde’s dandyism made him a "ladies’ man,” after his trial, such traits came to symbolise male homosexuality. ${ }^{6}$ In the case of Hall, the "mannish" lesbian became set in the public mind as the prototypical lesbian: "Without question, the most infamous mannish lesbian, Stephen Gordon, protagonist of The Well of Loneliness (1928), was created ... by Hall, herself an 'out' and militantly tie-wearing lesbian.”7

However, more recently, historians of sexuality such as Laura Doan have argued that Hall's masculinity has been misread as a clear, intentional statement of deviant homosexual identity and was in fact part of cutting-edge fashion of the 1920s: "Far from being perceived as the inventor and embodiment of deviant mannish lesbian style, Hall was seen as a thoroughly modern woman."8 Doan shows that masculine styles for women had multivalent significations during the 1920s and could be read differently according to the contexts in which they appeared. Furthermore, Doan argues that the focus on lesbian masculinity has allowed other formulations of sexual identity "slip through the net" of queer historiography, since "we spot gendered and sexual subjects who most closely approximate our modern categories, however we choose to name them."9 For this reason, when examining the nineteenth-century and early twentieth century, we may not see feminine lesbians because we have not been trained to look for them. When considering lesbian representation, therefore, we need to develop a broader view of queer self-fashioning that accommodates spectrums of femininity as well as masculinity. Recognising desire between two feminine women has the potential to further challenge the heteronormative assumption that every couple needs to include a man—or at least a masculine counterpart. Greater awareness of the history of lesbian femininities would also begin to address the much-discussed problem of femme 
"invisibility" and to acknowledge femme erotic independence. The latter is a term coined by Jewelle L. Gomez, who argues that "femme energy" is threatening because it implies "sexual desire, in a situation where women are not supposed to have desire, and certainly not for other women.”10

Pushing against foundational arguments by Lilian Faderman that saw sexual bonds between women as suppressed during the nineteenth century, more recently, Sharon Marcus has argued that close bonds between women (sometimes called “romantic friendships”) were actively encouraged in nineteenth-century culture. She suggests that through fashion plates, for example, women were encouraged to occupy "a male gaze” that viewed the elegant, feminine woman as both (potential) self and desired other. Therefore, fashionable femininity was not simply aimed at attracting male suitors but also soliciting attention from other women as erotically-charged rivals, friends and lovers. Marcus claims that during the nineteenth century:

female friendships peaceably coexisted with heterosexual marriage and moreover, helped to promote them ... mainstream femininity was not secretly lesbian, but openly homoerotic. Within the realm of domestic culture, Victorian women were as licenced to objectify women as were Victorian men. ${ }^{11}$

Marcus's research suggests that femininity played a central role in homoerotic attraction, blurring the supposedly lines between a heterosexual "mainstream" culture and so-called homosexual “deviancy.” Women looking at and desiring other women was actively encouraged in Victorian culture. 
How does this reflect and illuminate queer/lesbian culture today? ${ }^{12}$ Questions of gender, sexuality, fashion and identity politics remain hot topics within lesbian cultural and historical studies. Indeed, a recent "Femme Roundtable” emerging from the 2017 American Historical Association conference panel "Queering Femininity: Gender Normativity and Lesbian History” suggests that issues of femme visibility and representation are more relevant than ever. ${ }^{13}$ Chaired by Lauren Gutterman, the discussants take their cue from Esther Newton's work on the "mythic mannish lesbian." Newton proposes that whilst Hall's heroine, Stephen Gordon, has provided a focus for female masculinity, the story of her feminine lover, Mary Llewellyn "has yet to be told.” 14 The participants in this discussion, all currently engaged in historical research on femme subcultures and representation, seek to illuminate aspects of Mary's story and account for why femmes remain invisible in twenty-first century culture. Anastasia Jones suggests this is because:

The many 'Marys' of history spin more convoluted tales [than their butch counterparts]: narratives and categories defined by indefiniteness, flexibility, and, at times, concealment. But the intricacy of these identities make them worth tracing. In their liminality and elasticity, they can teach us about the possibilities and limits of queerness, femininity, and women's history. ${ }^{15}$

Cookie Woolner argues that femmes have been overlooked precisely because their ambiguity makes them threatening: 
This ability of feminine women to carry out queer relationships stealthily in some ways made them a larger threat to heteronormative society than the visibly queer masculine woman. The assumption of femme invisibility has been used strategically to keep queer relationships hidden, and this possibility also threatened to send heterosexual nuclear families into disorder. ${ }^{16}$

As Woolner suggests here, the femme's ability to hide in plain sight makes her particularly troubling to heteronormative visions of the family. The idea that a man could potentially mistakenly marry a sexually-deviant woman—-that you could not tell “just by looking,” was especially terrifying during the post-war era of McCarthyism, when women were encouraged to return to traditional gender roles and paranoia about secret deviance (with the potential to bring down the state) was rife. ${ }^{17}$ During the 1950 s, the golden age of the nuclear family, pulp fiction played on these fears in a tongue-incheek way, with titles such as Odd Girl (Artemis Smith, 1959) and The Girls in 3-B (Valerie Taylor, 1959) featuring cover images that showed highly feminine, attractive lesbians. The possibility that such women could infiltrate heterosexual society and seduce other women, as well as duping men, threatened the very foundations of American society.

During the Femme Roundtable, Shannon Weber agrees that femmes have been overlooked, partly because "femininity is devalued in most cultures" including within feminist theory, in which it is often viewed "as a stand-in for patriarchally-enforced passivity" and compulsory heterosexuality. ${ }^{18}$ Weber is by no means the first to notice that certain modes of feminism contribute to femme erasure. In 2002, Melanie Maltry 
and Kristin Tucker noted that strands of second-wave feminism during the 1960s and 1970s, suspicious of butch/femme roles, contributed to expunging femme identities:

Considering butch-fem(me) merely a replication of the heterosexual paradigm, lesbian-feminism sought to obliterate the confining butch-fem(me) roles. Androgyny, the new aesthetic of lesbian-feminism, sought to capture the positive qualities of both genders and embody them within the individual woman. ${ }^{19}$

In this model, femininity is seen as limited and restrictive, making it difficult to claim as subversive in comparison to expressions of female masculinity or androgyny that seemed to critique gender and explicitly challenge women's status as a sexual object arranged for a male heterosexual gaze. Feminist theory has therefore often ignored or misread the "transgressive implications of queer femme-ininities." 20 The femme writer Joan Nestle observed this in 1987 when she commented (of butch-femme identities) that it is "easy to confuse innovative or resisting style with a mere replica of the prevailing custom.”21

The challenge is to identify what makes the femme performance of gender different from heteronormative modes of femininity. As Alix Genter observes:

Just as whiteness does not constitute racial neutrality, normative gender presentation does not constitute gender's absence ... femmes’ experiences do not mirror those of similarly gendered straight women. Examining female femininity, and not only female masculinity, reveals the unique and varied ways 
that queer women have manipulated gender ideologies to produce a multiplicity of queer, gendered subjectivities in the lesbian past and present. ${ }^{22}$

But what does this have to do with nineteenth-century and early twentieth-century literature? The need to read lesbian femme-ininities differently is expressed by all of the Roundtable participants, and yet their examples are exclusively drawn from the midtwentieth century, post-war era. ${ }^{23}$ But such post-war femme identities did not arise out of a vacuum. As with butch identities which have their genealogy in the sexual inverts interviewed by Havelock Ellis and others, femme identities may be traced in the nineteenth century.

My purpose in retracing femme presence in nineteenth-century and early twentieth-century literature is therefore three-fold; firstly, to follow Sharon Marcus in her practice of "just reading ... what texts make manifest on their surface." 24 In this case, the manifest content is the presence of feminine homoerotically-inclined characters that have usually been overlooked in comparison to their more masculine counterparts. I agree with Marcus that such presences show the centrality of homoerotic desire to Victorian literature - and indeed, to the marriage plot —and that its subjects are not outcasts but are often conventionally feminine characters; femmes, in other words, hidden in plain sight.

Secondly, in engaging in such readings, I hope to trace (if only briefly) contexts for femme histories. Maltry and Tucker gesture to the "feminine inverts participating in homogenital contact in the early 1900s." ${ }^{25}$ My readings draw attention to the "feminine invert” and the Sapphist whose presence can be found in both sexological testimonies and the biographies of such figures as Natalie Barney, Isadora Duncan and others. 
Finally, my interpretations are also to some extent imaginative exercises that eschew strict historicism. As Virginia Blain asks: "Why should we narrow down our readerly options by turning our backs on the lesbian in any text? What might happen if we tried to stay open to such readings?”26 If nothing else, these nineteenth-century literary portrayals provide evidence that femininity can be read as queer and is not simplistically linked to heterosexuality/the marriage plot. These are fictions after all, and not historical accounts. Their narratives can therefore be mobilised in a multitude of ways, according to the purpose of the reader. As Dorothy Allison states: “Always I read as a lesbian ... But looking for self-defined lesbian books was never how I approached the subject. I always reinterpreted books to give me what I needed. All books were lesbian books." ${ }^{27}$ Drawing on Allison's words, I want to consider what it means to "read as a femme.”

My chapter therefore seeks to imaginatively re-read these fictional texts, looking for femme "types" that will prove inspiring to twenty-first century readers looking for femme identities. I will discuss three main examples. The first is Ginevra Fanshawe in Charlotte Brontë's Villette (1853), the extremely feminine coquette who relentlessly flirts with the heroine Lucy Snowe. The second is Connie Tracy in Eliza Lynn Linton's The Rebel in the Family (1880). This novel has received most attention for Bell Blount, a strident masculine character who "represents a milestone in the literary representation ... of lesbianism,” but Bell's "little wife” Connie has been overlooked, as have other more feminine characters in the novel that are coded as lesbian or bisexual (including the heroine Perdita, the eponymous "rebel”). ${ }^{28}$

Finally, I will look at Valérie Seymour in Radclyffe Hall’s The Well of Loneliness (1928), a character based on the notorious literary hostess Natalie Barney. I 
will suggest that Valérie Seymour's presence shows that we can trace an alternative tradition of lesbian style to the female masculinity modelled by Stephen Gordon—one founded on Barney’s Sapphic self-fashioning. In my final section, I will discuss how such floaty, draped “pagan” style is shared by many women poets of the time who expressed same-sex desire (such as Olive Custance, H.D. and Edna St. Vincent Millay) as well as dancers such as Isadora Duncan, connecting the fashionable Hellenic styles of the early twentieth-century back to the very origins of lesbian identity itself-Sappho of Lesbos. I will conclude by suggesting how paying attention to the nuances of lesbian femininity broadens our view of lesbian representation in the twenty-first century beyond the insulting (and outdated) stereotype of the "lipstick lesbian.” Focusing on "femme erotic independence," Gomez affirms that femininity is not designed solely to attract the heterosexual male gaze, and that female desire can exist independent of a masculine object. ${ }^{29}$ Recognising the complex history of lesbian femininities exposes the heteronormative logic of the mainstream collective imagination.

\section{'How pretty she was!': Charlotte Brontë, Villette (1853)}

Charlotte Brontë's Villette (1853) has often been read in relation to desire and sexuality. Even the novel's earliest readers noticed that this was a narrative about desire and its repression. For example, a reviewer for The Spector regarded the novel as decrying "the destiny of those women ... who are debarred from the exercise of those affections which are indeed the crown of a woman's happiness”-in other words, marriage and motherhood. ${ }^{30}$ Through the novel's morose heroine, the orphan Lucy Snowe, Brontë seemed to imagine a bleaker version of Jane Eyre’s fate. Lucy spends much of the novel friendless and alone_-or at least perceives herself as such. When she finally finds love 
with M. Paul, a fellow school teacher in Brussels, the novel concludes with M. Paul's implied death at sea, with Lucy declaring: “Let them picture union and a happy succeeding life,” leaving the novel's ending up to the disposition of the reader. ${ }^{31}$

However, later critics have interpreted Lucy’s sexuality as by no means straightforwardly heterosexual. Ann Weinstone, for example, in “The queerness of Lucy Snowe” regards Lucy’s persistent melancholy as arising from her repressed homosexuality. Patricia Duncker compares scenes in the novel to the school-set homoeroticism of Muriel Spark’s The Prime of Miss Jean Brodie. Lindley Nolan Swift analyses Lucy as a lesbian subject alongside characters from Daphne Du Maurier's Rebecca. As she shows, Lucy's queerest moments repeatedly take place alongside another female character: Ginevra Fanshawe, the hyper-feminine, coquettish schoolgirl whom Lucy claims to dislike intensely. Ginevra is a seventeen-year old pupil at Villette, the school where Lucy teaches. The women first meet on the voyage from London to Brussels; Lucy describes Ginevra as “[t]he other lady-passenger ... quite a girl, pretty and fair; her simple print dress, untrimmed straw-bonnet, gracefully worn, formed a costume plain to Quakerism: yet, for her, becoming enough” (Villette, 58). Swift argues that in this scene "Lucy veils her desire to observe Ginevra's beauty behind a concern for Ginevra’s ability to travel unescorted safely.”32

Once at Villette, Ginevra courts Lucy’s friendship: “she would forthwith have made me a sort of friend and confidant” (Villette, 93). Much to Lucy’s frustration, Ginevra emerges as lazy and self-indulgent, refusing to mend her elegant garments. Despite this, Lucy continues to reluctantly admire her beauty: "Notwithstanding these foibles ... how pretty she was! How charming she looked, when she came down on sunny Sunday morning, well-dressed and well-humoured, robed in pale lilac silk, and 
with her fair long curls reposing on her white shoulders” (Villette, 94). Lucy learns that Ginevra has an admirer that she calls "Isidore” (because his real name is not "very pretty"): "By glimpses and hints she had shown me, ... it was ere long proved that ardent admiration - perhaps genuine love - was at her command” (Ibid.). This sentence has a suggestive double-meaning; Lucy interprets Ginevra’s “glimpses and hints” as signs of "ardent admiration" but the emphasis on these significant looks passing between the two women suggests that this desire might lie between them, rather than originating with the mysterious Isidore.

Ginevra attends parties with her indulgent chaperon Mrs Cholmondeley. She requests dresses and other finery ("little expensive etceterae - gloves, bouquets, even trinkets”, Villette, 96) for these occasions, and displays herself for Lucy’s admiration:

she could not resist coming to my chamber to show herself in all her splendour. Beautiful she looked, so young, so fresh ... I viewed her from top to toe. She turned airily round that I might survey her on all sides. Conscious of her charms, she was in her best humour: her rather small blue eyes sparkled gleefully; she was going to bestow on me a kiss, in her school-girl fashion of showing her delight: but I said 'Steady! Let us be steady, and know what we are about, and find the meaning of our magnificence' - and so put her off at arm's length, to undergo cooler inspection. (Villette, 97)

As Marcus states, “Lucy’s constant rejection of Ginevra cannot be separated from her relish in recounting the scenes between them.” ${ }^{33}$ In the above instance, Lucy takes pains to note the kiss that didn't happen, and holds her at arm's length only to admire her the 
more with “cooler inspection.” The two eventually fall out over Ginevra’s manipulating “Isidore” to buy her trinkets, although Lucy’s moralistic anger seems a thinly-veiled cover for her jealousy of Ginevra’s secret lover. Ginevra however admits she does not really love him:

for he really thinks I am sensible. I am far more at my ease with you ... who take me at my lowest, and know me to be coquettish, and ignorant, and flirting, and fickle, and silly, and selfish, and all the other sweet things you and I have agreed are part of my character. (Villette, 100)

This statement reveals "Isidore" and Lucy to be connected as potential lovers in Ginevra’s mind. Lucy reacts by making “a strenuous effort to preserve that gravity and severity which ran risk of being shaken by this whimsical candour” (Ibid.). Once again, Lucy wilfully interprets Ginevra’s expressions of affection as "school-girl fashion” and child-like “whimsical candour,” as if acknowledging Ginevra as a desiring subject would be too dangerous and tempting. Her candour and her kiss must be read as whimsical rather than in earnest. ${ }^{34}$

Their relationship reaches its peak during a fete with theatrical entertainments, in which Lucy cross-dresses in the role of Ginevra’s male beau:

Ginevra ... had to coquette between two suitors, and managed admirably: in fact she was in her element. I observed that she once or twice threw a certain marked fondness, and pointed partiality in her manner towards me - the fop. ... Now I know I acted as if wishful and resolute to win and conquer. Ginevra seconded 
me; between us we half-changed the nature of the role, gilding it from top to toe. ... Ginevra was tender; how could I be otherwise than chivalric? ... What I felt that night, and what I did, I no more expected to feel and do, than to be lifted in a trance to the seventh heaven. (Villette, 155-56)

Duncker compares this scene to Spark’s Prime of Miss Jean Brodie (1961) and it can also be read as a precursor to Madchen in Uniform (1931). ${ }^{35}$ Kate Millett observes that Lucy is here aroused by Ginevra’s beauty to “a masculine lust.” ${ }^{36}$ However, whilst queer readings of this novel repeatedly focus on Lucy's cross-dressing role in this scene and her "masculine” desire, what of Ginevra's role here? What possible reasons can this uber-feminine woman have to “second” Lucy’s ardent desire and perform such “fondness" and tenderness?

One simple explanation is: to make her two male lovers jealous. This drama is played out in front of Ginevra’s two love rivals, Dr John (the real identity of “Isidore”) and Alfred de Hamal. However, this does not diffuse the homoeroticism of the scenein fact, it intensifies it. For the man Ginevra favours is de Hamal, described as a "little dandy ... pretty and smooth, and as trim as a doll: so nicely dressed, so nicely curled” (Villette, 161). As Lucy later observes, his “hands were scarce larger than Miss Fanshawe's own, and [I] suggested that this circumstance might be convenient, as he could wear her gloves at a pinch” (Villette, 162). Coming shortly after the crossdressing theatrics, de Hamal's femininity here is particularly significant. It aligns Ginevra's desire for de Hamal with desire for women, or at least a preference for a femininity that reflects her own. Dr John is rejected because he is too masculine: "His features were not delicate, not slight like those of a woman” (Villette, 164)—just as his 
name must be feminised into the more ambiguous-sounding Isidore in order to be “pretty” and therefore desirable to Ginevra.

From her love of trinkets and bon-bons to her preference for the doll-like de Hamal, Ginevra is a character who both embodies and desires hyper-femininity in all its forms. She is represented through images of sameness, such as the fair hair "reposing on her white shoulders” (Villette, 94). In contrast, “Lucy mistrusts her attraction to femininity ... Even when she encounters feminine qualities in a man ... Lucy is unsparing in her contempt." ${ }^{37}$ Marcus argues that Lucy fails to achieve heterosexual happiness because she refuses to connect with other women in the novel (including Ginevra, Pauline Home, and Madame Beck): "it is only the woman with no bosom friend who risks becoming, like Lucy Snowe, one whom no man will ever clasp to his heart in marriage.” ${ }^{38}$ But what happens if we read Villette not as the story of a tragic spinster, denied heterosexual marriage, or as that of repressed lesbian whose desire can only be expressed in male clothing? What if we concentrate instead on the narrative, barely concealed within it, of the confident feminine coquette with a bisexual preference for femininity? As Swift notes, “Ginevra takes on a more important role than many critics have awarded her in the past, ${ }^{39}$ propelling the romance plot in decidedly queer directions. An author of a "Femslash" blog has certainly noticed this:

Another time, perhaps, we will have a little chat about Villette and Agnes Grey, both of which are easily thrice as saturated with lesbian sensibility. Ginevra Fanshawe, that swaying, teasing, insouciant minx! — If you want to read a book about a coquetteish high femme who strikes up a dizzying, mocking relationship 
with a stone butch (who cross-dresses and makes ardent love to her in public during a school play), pick up a copy of Villette immediately. ${ }^{40}$

While Lucy as a "stone butch" may be an exaggeration, Ginevra as "high femme” is more convincing - even when she marries, she marries the most feminine man she can find.

To underscore this, it transpires that de Hamal himself is indeed a cross-dresser; disguising as a nun with "black gown and white veil” (Villette, 524) in order to visit Ginevra undetected. Ginevra herself reveals this to Lucy in a letter following her elopement: “how did you like the nun as a bedfellow? I dressed her up? - didn’t I do it well?” (Ibid.). Ginevra placing her cross-dressed, doll-like lover as the "bedfellow" of her female confidant is surely the ultimate mockery of Lucy's repressed desire for femme-ininity.

\section{'A thin, half-vitalized, vaporous little creature': Eliza Lynn Linton, The Rebel of the Family}

Twenty-seven years after Brontë's novel, the anti-feminist writer Eliza Lynn Linton published The Rebel of the Family (1880), a novel that contains "the first fully realised ‘modern' lesbian woman in English Literature.”41 In Bell Blount, a "handsome but bold and confident-looking woman,” Linton expresses her fears regarding female emancipation as potentially “unsexing." 42 Her heroine-Perdita Winstanley, the eponymous “rebel”—is drawn by Bell into a world of women's rights activism—or the “Shrieking Sisterhood” (Linton, 174). But whilst the novel attracts attention for its portrayal of the strident, masculine Bell, Linton’s portrayal of lesbian femininity is 
equally worthy of analysis. At the point of meeting Bell, Perdita has been rejected by her mother and sisters for failing to be ladylike and for being “a young person with principles” (Linton, 27). This forceful woman invites Perdita back to her house for tea, which is provided by her "little wife" Connie (Linton, 54):

This Connie Tracy was a pale, light-haired, mousey-faced little woman, with delicate features and large, light-blue, floating eyes; and she lived with Mrs. Blount on those terms of dependence and subservience which the champion of her sex found so infinitely degrading when they exist between men and women. (Linton, 56)

In its portrayal of Connie's subservience to Bell, Linton's novel anticipates the arguments of second-wave radical feminists in the later twentieth-century against butchfemme dynamics, which they view as replicating heterosexual gender relations. For example, Sheila Jeffreys claimed that the femme "seems to have experienced the social disadvantages in the lesbian community normally faced by the underclass of women in the heterosexual world.” 43 The extent of Connie’s subservience is later revealed as she grows increasingly jealous of Perdita, who threatens her position as Bell’s companion. The narrator comments: “Connie Tracy was as much Bell’s creature as if she had been a man's mistress to be discarded, without a pension, at pleasure and for the sake of a new face” (Linton, 173).

The difference between Bell and Connie is underscored not only by power differentials, but by physical contrasts. Where Bell wears “a kaleidoscopic arrangement of colours that was simply barbarous” (Linton, 49), Connie is insipid almost to the point 
of invisibility: “pale, light-haired, mousey.” This convention of the pale femme continues into the pulp lesbian novels of the 1950s; for example, Laura Landon, the femme protagonist of Ann Bannon’s cult lesbian novel, Odd Girl Out (1957) is described as having "a delicate face shaped like a thin white heart, with startling pale blue eyes and brows and lashes paler still. A face quaint and fine as a Tenniel sketch.” ${ }^{4}$ In contrast, Laura’s lover Beth, has dark hair. Bannon’s famous butch heroine, Beebo Brinker, also has black hair. The contemporary lesbian writer Radclyffe notes that her femmes are usually blonde, her butches tall and dark, and that this "polarization” is "an important element in creating the sexual tension which is so central to the romance." 45

As well as reinforcing gendered contrasts, such fair colouring seems to symbolise the femme's invisibility_her colourless features mean she fades into the background, whilst, conversely, her desirable blondeness underscores her ability to “pass” as a heterosexual object of desire. In line with Terry Castle’s vision of the apparitional lesbian as “a pale denizen of the night,” such pallor means the feminine lesbian fades from view. ${ }^{46}$ As Lisa Walker puts it "whiteness functions as what might be termed an ‘invisible sign’ of the femme’s difference.”47 This convention of representation is intensely troubling for its complete erasure of black lesbian femininities. The predominance of symbolic whiteness in representations of femmes means that "a femme woman of color ... will probably not be recognized as lesbian, first because she is not white and then because she is not butch.” ${ }^{48}$ Femmes of colour are thus rendered doubly invisible within a lesbian culture dominated by masculinity and whiteness.

To return to Connie, not only is she pale and mousey, she is literally sapped by the energy of her butch counterpart: 
Miss Tracy was a thin, half-vitalized, vaporous little creature - one of those lean kine not to be fattened up by any amount or quality of food - Mrs Blount’s whole person bore evidence of good living - of flesh made firm by meat and blood rich by stimulant. (Linton, 140)

Bell's energetic presence seems to be feeding off Connie in a disturbingly vampiric way, echoing Connie’s subservient position. Moreover, Connie is depicted as less natural than Bell, as the women smoke together:

'I should miss my weed dreadfully, I confess,' answered Connie; and Perdita thought how odd it sounded to hear that slang word from this pale, delicate, refined-looking woman, with her innocent white eyelashes and sharp peaked mouse-shaped face. It was far more incongruous than with Mrs. Blount, who had a certain flourish of masculinity about her that made a cigarette between her full hard lips infinitely more natural ... than the angular attitude of Constance Tracy, who only made herself an ungraceful woman by all that she did and could never transform herself into the handsome hybrid which her friend strove hard to appear and to be. (Linton, 143)

Here the masculinised female invert (or "handsome hybrid”) can pull off smoking, whilst the feminine woman is even more an aberration, since she does not have the natural masculinity to carry off such acts. Connie’s identity as a New Woman and (implicitly) a lesbian is thus depicted as an inherently false and unconvincingly 
performance as her essential femininity (once again embodied in her diminutive stature and pale features) undermines the act. This recalls the persistent modern perception of the femme as inauthentic. ${ }^{49}$

Connie is not the only femme present in Linton's novel. Aside from Bell, the novel has also attracted interest for a scene involving lectures on the "Degradation of Married Women” (Lindon, 183). Deborah Meem points out that “[p]resent at the meeting is a woman who will soon, thanks to Havelock Ellis, be a recognizable type, termed a mannish lesbian or a congenital invert, but who, in 1880, can only be described as she appears." ${ }^{50}$ Meem is referring to the following speaker:

One was a woman with close-cropped hair, a Tyrolese hat with a cock’s feather at the side, a shirtcollar and a shirt-front, a waist-coat and a short jacket. In everything outward she was like a man, save for whiskers - which, however, she simulated in a short kind of cheek-curl; and for moustaches - which were more than indicated. (Linton, 188)

However, in her focus on this masculine woman, Meem misrepresents the variety of female types present in this scene. The feminine women who speak at the meeting outnumber the masculine individual described. The first to speak is "a lady from America, with ... a toilette from Paris that would have made the typical duchess envious” (Linton, 186). Here Linton is clearly playing on stereotypes of the emancipated wealthy American, importing her ideas to British shores. Another speaker is a model of Pre-Raphaelite femininity: “a breezy, aesthetic-looking creature in a Pre- 
Raphaelite costume of green, long and lean as a lizard” (Linton, 188). The most popular speaker is:

a pretty, graceful, affected little person ... she herself was made much of. She was the Venus of the Emancipated Olympus; and the leaders knew the value of her wavy, golden hair and large blue eyes, her lovely curved mouth and slender figure. (Linton, 187)

The reference here to the leaders knowing “the value of” this speaker's attractiveness is interesting; on the one hand, this could mean the power to attract men to the movement, or to undermine the stereotypes of emancipated women as unattractive. In other words, this pretty speaker provides good PR for the women’s movement. However, given that the "leaders" are women (including Blount herself) and the potential recruits are women too (such as Perdita) the implication here is that "golden hair" and "blue eyes" provide suitable bait to draw other women into the movement. In other words, the strategy is to arouse homoerotic passions in order to entice potential new recruits to the cause.

Whilst her depiction of Bell emphasises her charm and magnetism, Linton remains intensely suspicious of femininity, a paranoid rejection that seems to echo Lucy Snowe's repulsion to all things feminine. Her later novel In Haste and at Leisure (1895) continues to associate the "fast” New Woman with excessive femininity rather than masculinity. For example, the women of the Excelsior Club (the "nucleus of the new order of feminine supremacy”) are described as “pretty and always supremely welldressed; and they looked of the kind to lead men astray with their personal witcheries.”51 As Constance Harsh notes, “[u]nder their tutelage [the novel’s 
protagonist] Phoebe becomes the overdressed, cosmetically enhanced, bleached-blonde vixen Linton loves to hate.”52 As Phoebe transforms into an uber-feminine vamp, Linton's descriptions linger over her appearance with a curious "mixture of

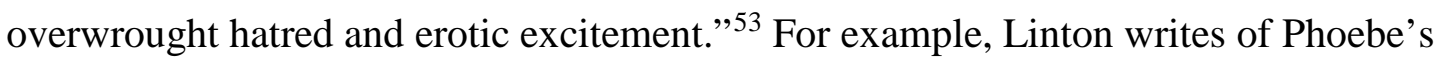
gown of "soft, flesh-coloured silken stuff, fitting as perfectly as if it had been a second skin, so that you scarcely knew which was flesh and which was silken stuff ... Arms neck, and bust were bare, and gleaming white and warm” (Linton, 1895: 259-60). In its emphasis on tactility and repetition, this description reads less like a condemnation of Phoebe’s public display of her flesh and more like a conflicted indulgence in a desiring gaze. Like Lucy holding Ginevra “at arm’s length, to undergo cooler inspection,” Linton is drawn and yet repelled by her female creations' voluptuous femininity.

\section{‘A creature born out of her epoch': Radclyffe Hall, The Well of Loneliness}

Finally, I want to turn to Radclyffe Hall’s iconic novel, The Well of Loneliness (1928). Rather than focusing on Hall's inverted protagonist Stephen Gordon as many other critics have done, I want to examine the portrayals of femme-ininity found within the novel, including Stephen’s lovers Angela Crossby and Mary Llewellyn, and the salon hostess Valérie Seymour. Angela, an American and former actress, is Stephen’s first love and is described thus at their first meeting:

Angela Crossby was amazingly blonde, her hair was not so much golden as silver. She wore it cut short like a mediaeval page ... Her skin was very white, and Stephen decided that this woman would never have a great deal of colour, nor would her rather wide mouth be red, it would always remain the tint of pale 
coral. All the colour that she had seemed to lie in her eyes, which were large and fringed with long fair lashes. Her eyes were of rather an unusual blue that almost seemed to be tinted with purple, and their candid expression was that of a child very innocent it was, a trustful expression. ${ }^{54}$

Here, once again, we witness the overdetermined whiteness of the femme: yet again she is silver-blonde, lacks colour, has blue eyes and is child-like. Only the "purple" colour of Angela's eyes and her mediaeval page-boy cut hint at her concealed queerness. Lisa Walker argues that "in The Well the femme is marked by the signifier of her invisibility: whiteness.” 55 As we have seen, the representation of the pallid femme has a much longer history than Hall’s novel; think of Ginevra’s “fair long curls reposing on her white shoulders” (Villette, 94). As Walker observes, whiteness functions in a number of different ways in Hall's novel, signifying “the idealized qualities of innocence, purity, and naturalness on the one hand, and of corruption, impurity, and artificiality on the other."56

In Angela’s case, her whiteness represents a “bloodless, reptilian ... blanched exoticism" (Ibid., 46). She is described as being "like some queer flower that had grown up in darkness, like some rare, pale flower without blemish or stain” (Hall, 145). Angela only lacks stain, we eventually learn, because she is artificial and false, ultimately betraying Stephen. Immediately after this description of Angela, Stephen flushes and offers to drive her home. Stephen's own reactive skin betrays her desire (she is constantly flushing, blushing, shaking and trembling), while the femme remains blank and treacherously unreadable. Angela later mentions in passing that her mother was "the descendant of women who had owned many slaves” (Hall, 201-02). Walker proposes 
that the novel "puts tropes of racial difference into circulation with discourses of sexuality." ${ }^{57}$ In this sense, Stephen is subtly aligned with blackness and the oppressed racial other in contrast to the cruel white femme Angela.

Mary Llewellyn’s whiteness certainly signifies innocence- - to underscore this, she is first represented sleeping, with Stephen free to gaze on her:

The girl slept the sleep of complete exhaustion, breathing heavily with her head on her arm; her pale and rather triangular face was that of someone who was still very young, not much more than nineteen or twenty. The pallor of her skin was accentuated by the short black lashes which curled back abruptly, by the black arched eyebrows and dark brown hair - sleek hair which grew to a peak on the forehead, and had recently been bobbed for the sake of convenience. ... For more than a minute Stephen considered the immature figure of Mary Llewellyn. (Hall, 318)

Stephen estimates Mary’s young age, and the "pale and triangular face” presages that of Laura Landon. However, the pale femininity of this description is intriguingly undercut-Mary's lashes are "short” yet curled, her hair is "black” rather than the usual blonde, and it is "bobbed"-suggesting the garconne style of the modern flapper. We are swiftly told that this is only "for the sake of convenience" (how does Stephen know this? Can we read this as a hasty disavowal of Mary’s potential queerness?).

In Paris, Stephen meets a strikingly different femme character. This is Valérie Seymour, the wealthy salon hostess based on Natalie Clifford Barney: 
Valérie came forward with a smile of welcome. She was not beautiful nor was she imposing, but her limbs were very perfectly proportioned, which gave her a fictitious look of tallness. She moved well, with the quiet and unconscious grace that sprang from those perfect proportions. Her face was humorous, placid and worldly; her eyes very kind, very blue, very lustrous. She was dressed all in white, and a large white fox skin was clasped round her slender and shapely shoulders. For the rest she had masses of thick fair hair, which was busily ridding itself of its hairpins; one could see at a glance that it hated restraint, like the flat it was in rather splendid disorder. (Hall, 279)

Valerie’s first appearance here echoes Havelock Ellis’s account of the feminine inverted woman: "Their faces may be plain or ill made, but not seldom they possess good figures ... they are always womanly. One may, perhaps, say that they are the pick of the women whom the average man would pass by."58 Since Hall drew on Ellis's work for her portrayal of Stephen, it is not surprising that his case studies should infuse her portrayal of the feminine invert. However, Hall's emphasis on Valerie’s perfect proportions also lends her a classical, statuesque quality like that of an Ancient Greek marble. Indeed, Barney drew her ideal of beauty from Ancient Greek literature and art, particularly the lyrics of Sappho, considered the first lesbian, who lived on Mitylene with a group of dedicated female followers. Barney and her lovers, including the poets Renée Vivien and Olive Custance, dramatized their lesbian passion through photographic tableaux, posed as nymphs, shepherdesses, princes, princesses and goddesses. As Karla Jay explains, Barney's ideal of beauty (which she also sought to embody) was that of the "virgin, cold and inaccessible ... the feminine ideal chiselled in marble." 59 Stillness, 
pallor, long draped, diaphanous gowns (sometimes nudity) and the perfect statuesque pose were part of this ideal. Something of this comes through in Hall's portrayal—in the grace of Valerie's lithe limbs and her white outfit, whilst the "white fox skin” on her shoulders hints at Barney’s reputation as a huntress or Amazon (one of her many nicknames). This role aligns her both with the virgin goddess Artemis (goddess of women, the hunt and the moon) but also signifies her reputation as a relentless huntressseductress of women.

In contrast to Hall, Barney defiantly rejected sexological visions of the lesbian as a masculine invert. She viewed both femininity and lesbianism as superior to masculinity and heteronormativity. As Shari Benstock explains, Barney was distrustful of female masculinity, preferring instead to develop a classically-inflected feminine beauty:

Barney herself spent a lifetime trying to revise the public and private images held by the larger community and by lesbian women themselves. She provided a role model in her own behaviour ... she objected to any form of dress or behavior that suggested homosexual women were really men trapped in women's bodies. ${ }^{60}$

In marked contrast to Hall's sexual inversion, Barney emphasised the femininity of the lesbian body "draped it in Grecian robes or photographed its lithe contours by moonlight ... Barney’s own body conformed to the ideal of female beauty she so praised.”61 In doing so, Barney sought to reincarnate and embody Sapphic ideals; according to Jane McIntosh Snyder and Barbara Fowler, this distinctive "Sapphic 
aesthetic" is broadly characterised by three elements: charis ("grace”), habrosune (“delicacy”), and poikilia (“variegation”). ${ }^{62}$ Such qualities are embodied through physical beauty: "to the Archaic mind-set physical beauty is attributable to the three Charites." 63 Thus, rather than a shallow distraction, feminine qualities of beauty, youth, delicacy, and grace are a gift from the goddesses and a source of women's inherent power. Hence, Barney sought to showcase this power to her best advantage.

Though their styles are so markedly different, Stephen Gordon recognises Valérie as “creature born out of her epoch, a pagan chained to an age that was Christian” (Hall, 281). As Walker comments, to the inverted Stephen (and Hall) "Valérie is a creature apart because she is that logical impossibility—the truly lesbian feminine woman” 64 This magical and enigmatic femme cannot truly exist in the real world. Valérie’s unruly fair hair symbolises her untimely position as an unrestrained pagan, and she is also associated with decadent Orientalism (she wears an oriental fragrance), in contrast to Stephen’s very English Christianity. As Walker argues, Valérie is ultimately marginalised within the plot of The Well because "she complicates the novel's dominant representation of the femme as emotionally weak and financially dependent” (Ibid., 51). Although she could be a potential love interest for Stephen, Valérie slips out of view, leaving Stephen to bear the yoke of inversion on her broad shoulders. Valérie is portrayed as "superficial, non-existent, shifting and anonymous" (Ibid., 54) — the dubious qualities associated with the femme in the later twentiethcentury.

\section{Femme Legacies}


But whilst Hall depicts her as “a creature born out of her epoch,” Barney was not alone in adopting the draped chitons of Sappho in the early 1900s—in fact, she was ahead of her time. By the 1920s, draped Hellenic gowns and the ecstatic “Greek dance” were all the rage. As Deborah Saville observes, Greenwich Village bohemians celebrated:

[t]he idea of the body as a shrine and expressing oneself through art, dance, movement, and sensuality facilitated the use of scarves, beads, robes, cropped hair and cosmetics. Exotic themes in dress and culture occurred in conjunction with fashionable views on sexuality and psychology. ${ }^{65}$

Such ideas were embodied in the dances of Isadora Duncan and Loie Fuller and the fashions of designers Paul Poiret and Mariano Fortuny. The latter, with his Knossos scarf and clinging Delphos gown, dressed women like Greek goddesses in pleated silk dresses that clung to every curve (wearers were rumoured to abjure underwear). Lady Diana Cooper recalls Princess Violette Murat, a member of Barney’s lesbian circle, wearing

the first of these tanagra-esque garments, later sold by thousands ... made by Fortuny of Venice - timeless dresses of pure thin silk cut severely straight from shoulder to toe, and kept wrung like a skein of wool. In every crude and subtle colour, they clung like mermaid’s scales. ${ }^{66}$

Lesbian and bisexual celebrities favoured such designers: the actress Eleonora Duse, Marchesa Casati (lover of Romaine Brooks), the poet Edna St. Vincent Millay, Barney 
herself all wore Fortuny and Poiret gowns. Meanwhile, the poet H.D. dressed as Sappho and was photographed "in Hellenistic profile, with her hair in a chignon, seated in a chair of neoclassical design, recalling classical representations of the muses” ${ }^{\text {"67 }}$ whilst Alice B. Toklas “dressed in ever more feminine costumes, affecting a gypsy look, complete with flowered, flowing dresses and long earrings” 68

None of these styles are masculine and yet all expressed sexual alterity on the part of their wearers. So whilst we can trace one distinct tradition of lesbian selffashioning and representation — that of female masculinity, most famously embodied by Radclyffe Hall—we can also trace another, more submerged tradition—that of Natalie Barney and her ideals of Sapphic femininity. Several scholars have traced this alternate manifestations of lesbianism (Jay, Benstock, Martha Vicinus, Leila Rupp) but the question of how to read such femininity still bears asking, especially in light of current debates about femme identity. ${ }^{69}$ Did these feminine lesbians wear such clothing in order to "pass" as straight? Did they understand a system of femme codes and recognise these in others? Was this to some extent an ironic parody of gender, akin to Sandra M. Gilbert and Susan Gubar’s notion of “female impersonation,” exaggerating one’s femininity in order to emphasise the artificiality of all gender? ${ }^{70}$ Or did they view their femininity as an innate essence to be expressed through dress?

Finally, these questions and the analyses contained within this chapter have serious implications for femme identities today. As Rebecca Rugg puts it: “Announcing oneself as a proud femme dyke is especially complicated ... [when] the largely white lipstick-lesbian culture is assimilationist and butch-hating.”71 As Maltry and Tucker argue, lipstick lesbian culture is predicated on being "straight acting” and "no way seeks to disrupt femininity or normative heterosexual practices.”72 How do we distinguish 
between the "lipstick lesbian" and the queer femme, and do such distinctions matter? Moreover, as we have seen, the historical representation of the femme is predicated on whiteness, and on other forms of cultural privilege too-such as class privilege (many of these early twentieth-century lesbians were incredibly wealthy and therefore to some extent beyond reproach). Another element that I have not addressed here is the distinctive position of bisexual women, who often face intense prejudice and suspicion within queer communities. Reconciling Barney’s vision of the femme ideal as slender, white, able-bodied and virginal with the lived reality of multifarious embodied femme identities (including those of femme trans women) poses a number of difficult challenges. If nothing else, I hope this chapter has shown that lesbian femme-ininity is far from simple - that there are in fact multifarious femininities and that their manifestations, presences and possibilities are still to be uncovered.

\section{Works Cited}

Allison, Dorothy. “Every Book Is a Lesbian Book.” Salon, June 10, 1999.

http://www.salon.com/1999/06/10/lesbian_books/ (accessed April 13, 2017).

Allott, Miriam, ed. The Brontës: The Critical Heritage. London: Kegan Paul, 1974.

Bannon, Ann. Odd Girl Out. San Franscico: Cleis Press, 2001. First published in 1957.

Benstock, Shari. Women of the Left Bank. Austin: Texas University Press, 1989.

Blain, Virginia. “Sexual Politics of the (Victorian) Closet; or, No Sex Please - We're Poets.” In Women's Poetry, Late Romantic to Late Victorian, Gender and Genre, 1830-1900, edited by Isobel Armstrong and Virginia Blain, 135-63. Basingstoke: Palgrave, 1999.

Blair, Karen L. and Rhea Ashley Hoskin. "Experiences of Femme Identity: Coming out, 
Invisibility and Femmephobia.” Psychology \& Sexuality 6, no. 3 (2015): 229-44. Brontë, Charlotte. Villette. Edited by Helen Cooper. London: Penguin, 2004.

Castle, Terry. The Apparitional Lesbian: Female Homosexuality and Modern Culture. New York: Columbia University Press, 1993.

Collecott, Diana. H. D. and Sapphic Modernism. Cambridge: Cambridge University Press, 1999.

de Osma, Guillermo. Fortuny: His Life and Work. New York: Skira Rizzoli, 2016.

Doan, Laura. Disturbing Practices: History, Sexuality, and Women's Experience of Modern War. Chicago: University of Chicago Press, 2013.

—. Fashioning Sapphism: The Origins of a Modern English Lesbian Culture. New York: Columbia University Press, 2001.

Duncker, Patricia. “The Suggestive Spectacle: Queer Passions in Brontë’s Villette and The Prime of Miss Jean Brodie.” In Theorizing Muriel Spark: Gender, Race, Deconstruction, edited by Martin McQuillan, 67-77. Basingstoke: Palgrave Macmillan, 2002.

Ellis, Havelock. Sexual Inversion. Philadelphia, P.A.Davis and Co, 1901.

Femme Histories Roundtable. Chair: Lauren Gutterman, Participants: Alix Genter, Anastasia Jones, Amanda Littauer, Shannon Weber, and Cookie Woolner. February 16, 2017. http://notchesblog.com/2017/02/16/femme-historiesroundtable-part-i/ (accessed March 30, 2017).

Foucault, Michel. The History of Sexuality, Vol. 1: An Introduction. Translated by Robert Hurley. New York: Vintage, 1990.

Fowler, Barbara Hughes. “The Archaic Aesthetic.” The American Journal of Philology 105, no. 2 (Summer, 1984): 119-49. 
Gilbert, Sandra M. and Susan Gubar. "Female Female Impersonators: The Fictive Music of Edna St. Vincent Millay and Marianne Moore.” In No Man’s Land: The Place of the Woman Writer in the Twentieth Century, Volume 3: Letters from the Front, by Gilbert and Gubar, 57-120. New Haven: Yale University Press, 1994.

Gomez, Jewelle L. “Femme Erotic Independence.” In Munt and Smyth, Butch/Femme, 101-08.

Hall, Radclyffe. The Well of Loneliness. New York: Blue Ribbon Books, 1928.

Harsh, Constance. “Eliza Lynn Linton as New Woman Novelist.” In The Rebel of the Family, by Eliza Lynn Linton, 456-74. Ontario, Canada: Broadview, 2002. Jay, Karla. The Amazon and the Page: Natalie Clifford Barney and Renée Vivien. Indiana: Indiana University Press, 1988.

Jeffreys, Sheila. “Butch and Femme: Then and Now.” In Not a Passing Phase: Reclaiming Lesbians in History, 1840-1985, edited by Lesbian History Group, 158-87. London: The Women’s Press, 1989.

Johnson, David K. The Lavender Scare. Chicago: Chicago University Press, 2004. Linton, Eliza Lynn. In Haste and at Leisure. 3 vols. London: Heineman, 1895.

—. The Rebel of the Family. Edited by Deborah T. Meem. Ontario, Canada: Broadview, 2002.

Maltry, Melanie and Kristin Tucker. “Female Fem(me)ininities.” Journal of Lesbian Studies 6, no. 2 (2002): 89-102.

Marcus, Sharon. Between Women: Friendship, Desire, and Marriage in Victorian England. Princeton, New Jersey: Princeton University Press, 2007.

Meem, Deborah T. “Eliza Lynn Linton and the Rise of Lesbian Consciousness.” Journal of the History of Sexuality 7, no. 4 (April 1997): 537-60. 
—. “Introduction.” In The Rebel of the Family, by Eliza Lynn Linton, 9-16. Ontario, Canada: Broadview, 2002.

Millett, Kate. “From ‘The Sexual Revolution’” In The Brontë Sisters: Critical Assessments, Vol. 3, edited by Eleanor McNees, 650-58. Mountfield: Helm, 1996. Munt, Sally R. and Cherry Smyth, eds. Butch/Femme: Inside Lesbian Gender. London: Cassell, 1998.

Munt, Sally R. “Introduction.” In Munt and Smyth, Butch/Femme, 1-11.

Nestle, Joan. “The Femme Question.” In The Persistent Desire: A Femme-Butch Reader, edited by Joan Nestle, 138-46. Boston: Alyson Publications, 1987.

Newton, Esther. “The Mythic Mannish Lesbian: Radclyffe Hall and the New Woman.” Signs 9, no. 4 (Summer, 1984): 557-75.

Ortberg, Mallory. “Femslash Friday: Jane Eyre.” The Toast, May 9, 2014. http://thetoast.net/2014/05/09/femslash-friday-jane-eyre/ (accessed April 10, 2017)

Radclyffe. “The Hero and The Lady.” In The Emergence of the Lesbian Romantic Hero and the Plot She Thrives In. DC Bardfest, October 2004. http://www.lorillake.com/Lady-Hero.html (accessed April 10, 2017).

Rugg, Rebecca Ann. “How Does She Look?” In Femme: Feminists, Lesbians, and Bad Girls, edited by Laura Harris and Elizabeth Crocker, 175-89. New York: Routledge, 1997.

Rupp, Leila. Sapphistries: A Global History of Love between Women. New York: New York University Press, 2011.

Saville, Deborah A. “Dress and Culture in Greenwich Village.” In Twentieth-Century American Fashion, edited by Linda Welters and Patricia A. Cunningham, 33-56. Oxford: Berg Publishers, 2005. 
Showalter, Elaine. “Introduction.” In Daughters of Decadence, vii-xx. New Brunswick, NJ: Rutgers University Press, 1993.

—. Sexual Anarchy: Gender and Culture at the Fin de Siècle. London: Virago, 1992.

Sinfield, Alan. The Wilde Century: Oscar Wilde, Effeminacy and the Queer Moment. New York: Columbia University Press, 1994.

Snyder, Jane McIntosh. Lesbian Desire in the Lyrics of Sappho. New York: Columbia University Press, 1997.

Swift, Lindley Nolan. "Lesbian Texts and Subtexts: [De] Constructing the Lesbian Subject in Charlotte Brontë’s Villette and Daphne Du Maurier’s Rebecca.” MA diss., North Carolina State University, 2006.

http://repository.lib.ncsu.edu/ir/handle/1840.16/2145 (accessed April 10, 2017).

Vicinus, Martha. Intimate Friends: Women Who Loved Women, 1778-1928. Chicago: Chicago University Press, 2004.

von Kraft-Ebing, Richard. Psychopathia Sexualis. Translated by R. J. Rebman. New York: Rebman, n.d.

Walker, Lisa, Looking like What You Are: Sexual Style, Race, and Lesbian Identity. New York: New York University Press, 2001.

\footnotetext{
n.d.), 399.

${ }^{1}$ Richard von Kraft-Ebing, Psychopathia Sexualis, trans. RJ. Rebman (New York: Rebman,

${ }^{2}$ Elaine Showalter, “Introduction,” Daughters of Decadence (New Brunswick, NJ: Rutgers University Press, 1993), x.

${ }^{3}$ Elaine Showalter, Sexual Anarchy: Gender and Culture at the Fin de Siècle (London: Virago, 1992).
} 
${ }^{4}$ Michel Foucault, The History of Sexuality, Vol. 1: An Introduction, trans. Robert Hurley (New York: Vintage, 1990), 43.

${ }^{5}$ Alan Sinfield, The Wilde Century: Oscar Wilde, Effeminacy and the Queer Moment (New York: Columbia University Press, 1994).

${ }^{6}$ Ibid., 4.

${ }^{7}$ Esther Newton, “The Mythic Mannish Lesbian: Radclyffe Hall and the New Woman,” Signs 9, no. 4 (Summer, 1984): 559.

${ }^{8}$ Laura Doan, Fashioning Sapphism: The Origins of a Modern English Lesbian Culture (New York: Columbia University Press, 2001), 113.

${ }^{9}$ Laura Doan, Disturbing Practices: History, Sexuality, and Women's Experience of Modern War (Chicago: University of Chicago Press, 2013), 104.

10 Jewelle L. Gomez, "Femme Erotic Independence,” Butch/Femme: Inside Lesbian Gender, eds Sally R. Munt and Cherry Smyth (London: Cassell, 1998), 104.

${ }^{11}$ Sharon Marcus, Between Women: Friendship, Desire, and Marriage in Victorian England (Princeton, NJ: Princeton University Press, 2007), 2-3.

${ }^{12}$ I use the terms "lesbian” and "queer" interchangeably throughout this chapter, although I am aware others prefer to maintain distinctions between them.

${ }^{13}$ See "Femme Histories Roundtable," February 16, 2017, chaired by Lauren Gutterman; the participants are: Alix Genter, Anastasia Jones, Amanda Littauer, Shannon Weber, and Cookie Woolner. The two-part roundtable can be found at http://notchesblog.com/2017/02/16/femme-histories-roundtablepart-i// (accessed March 30, 2017).

${ }^{14}$ Newton, "The Mythic Mannish Lesbian,” 575 (see note 7).

${ }^{15}$ Jones, "Roundtable Part I" (see note 13).

16 Woolner, "Roundtable Part I" (see note 13).

${ }^{17}$ During 1950s McCarthyism, homosexuals were viewed as security risks due to their susceptibility to blackmail. They were also seen as potential communist sympathisers. See David K. Johnson, The Lavender Scare (Chicago: Chicago University Press, 2004).

${ }^{18}$ Weber, "Roundtable Part I” (see note 13).

${ }^{19}$ Melanie Maltry and Kristin Tucker, “Female Fem(me)ininities,” Journal of Lesbian Studies 6, no. 2 (2002): 93.

${ }^{20}$ Weber, "Roundtable Part I" (see note 13).

${ }^{21}$ Joan Nestle, "The Femme Question," in The Persistent Desire: A Femme-Butch Reader, ed. Joan Nestle (Boston: Alyson Publications, 1987), 141.

${ }^{22}$ Genter, "Roundtable Part II" (see note 13).

23 "Femmeinities" is a term coined by Clare Whatling, see Sally R. Munt, "Introduction," in Butch/Femme, 5 (see note 10).

${ }^{24}$ Marcus, Between Women, 3 (see note 11).

${ }^{25}$ Maltry and Tucker, "Female Fem(me)ininities," (see note 19).

${ }^{26}$ Virginia Blain, "Sexual Politics of the (Victorian) Closet; or, No Sex Please - We're Poets," Women's Poetry, Late Romantic to Late Victorian, Gender and Genre, 1830-1900, eds Isobel Armstrong and Virginia Blain (Basingstoke: Palgrave, 1999), 142.

${ }^{27}$ Dorothy Allison, “Every Book Is a Lesbian Book,” Salon, June 10, 1999, http://www.salon.com/1999/06/10/lesbian books/ (accessed April 13, 2017).

${ }^{28}$ Deborah T. Meem, "Introduction," in The Rebel of the Family, by Eliza Lynn Linton (Ontario, Canada: Broadview, 2002), 13.

${ }^{29}$ Gomez, "Femme Erotic Independence," (see note 10).

${ }^{30}$ Qtd. in Miriam Allott, ed., The Brontës: The Critical Heritage (London: Kegan Paul, 1974), 182.

${ }^{31}$ Charlotte Brontë, Villette, ed. Helen Cooper (London: Penguin, 2004), 546; hereafter cited in text. For the ending of the novel, see note 9, 603 of this edition.

${ }^{32}$ Lindley Nolan Swift, "Lesbian Texts and Subtexts: [De] Constructing the Lesbian Subject in Charlotte Brontë's Villette and Daphne Du Maurier's Rebecca,” (MA diss., North Carolina State University, 2006), http://repository.lib.ncsu.edu/ir/handle/1840.16/2145 (accessed April 10, 2017).

${ }^{33}$ Marcus, Between Women, 103 (see note 11).

${ }^{34}$ To contextualise this, a girl could be married at 12 without parental consent this period, although twenty was considered a desirable age to marry. At seventeen, Ginevra is therefore considered mature and marriageable. 
${ }^{35}$ Patricia Duncker, "The Suggestive Spectacle: Queer Passions in Brontë's Villette and The Prime of Miss Jean Brodie,” Theorizing Muriel Spark: Gender, Race, Deconstruction, ed. Martin McQuillan (Basingstoke: Palgrave Macmillan, 2002), 67-77.

${ }^{36}$ Kate Millett, "From 'The Sexual Revolution'," in The Brontë Sisters: Critical Assessments, ed. Eleanor McNees, Vol. 3 (Mountfield: Helm, 1996), 651.

${ }^{37}$ Marcus, Between Women, 106 (see note 11).

${ }^{38}$ Ibid., 108.

${ }^{39}$ Swift, "Lesbian Texts and Subtexts," 22 (see note 32).

${ }^{40}$ Mallory Ortberg, "Femslash Friday: Jane Eyre,” The Toast, May 9, 2014, http://thetoast.net/2014/05/09/femslash-friday-jane-eyre/ (accessed April 10, 2017).

${ }^{41}$ Meem, "Introduction," in The Rebel of the Family, by Linton, 11 (see note 28).

${ }^{42}$ Eliza Lynn Linton, The Rebel of the Family, ed. Deborah T. Meem (Ontario, Canada: Broadview, 2002), 48, first published in 1880; hereafter cited in text.

${ }^{43}$ Sheila Jeffreys, "Butch and Femme: Then and Now," Not a Passing Phase: Reclaiming Lesbians in History, 1840-1985, ed. Lesbian History Group (London: The Women’s Press, 1989), 166.

${ }^{44}$ Ann Bannon, Odd Girl Out (San Franscico: Cleis Press, 2001), 3; first published in 1957.

${ }^{45}$ Radclyffe, "The Hero and The Lady," in The Emergence of the Lesbian Romantic Hero and the Plot She Thrives In, DC Bardfest, October 2004, http://www.lorillake.com/Lady-Hero.html (accessed April 10, 2017).

${ }^{46}$ Terry Castle, The Apparitional Lesbian: Female Homosexuality and Modern Culture (New York: Columbia University Press, 1993), 2.

${ }^{47}$ Lisa Walker, Looking like What You Are: Sexual Style, Race, and Lesbian Identity (New York: New York University Press, 2001), 45. Walker specifically addresses the racial politics of lesbian pulp in her chapter "Lesbian Pulp in Black and White," 103-38.

${ }^{48}$ Ibid., 207.

${ }^{49}$ See Karen L. Blair and Rhea Ashley Hoskin, "Experiences of Femme Identity: Coming out, Invisibility and Femmephobia,” Psychology \& Sexuality 6, no. 3 (2015): 229-44.

${ }^{50}$ Deborah T. Meem, "Eliza Lynn Linton and the Rise of Lesbian Consciousness," Journal of the History of Sexuality 7, no. 4 (April 1997): 550-51. cited in text.

${ }^{51}$ Eliza Lynn Linton, In Haste and at Leisure, 3 vols (London: Heineman, 1895), 1: 71; hereafter

${ }^{52}$ Constance Harsh, "Eliza Lynn Linton as New Woman Novelist," in The Rebel of the Family, by Eliza Lynn Linton (Ontario, Canada: Broadview, 2002), 463.

${ }^{53}$ Ibid., 462.

${ }^{54}$ Radclyffe Hall, The Well of Loneliness (New York: Blue Ribbon Books, 1928), 144; hereafter cited in text.

${ }^{55}$ Walker, Looking like What You Are, 44 (see note 47).

${ }^{56}$ Ibid., 45.

${ }^{57}$ Ibid.

${ }^{58}$ Havelock Ellis, Sexual Inversion (Philadelphia: P.A. Davis and Co, 1901), 133.

${ }^{59}$ Karla Jay, The Amazon and the Page: Natalie Clifford Barney and Renée Vivien (Indiana: Indiana University Press, 1988), 116.

${ }^{60}$ Shari Benstock, Women of the Left Bank (Austin: Texas University Press, 1989), 11.

${ }^{61}$ Ibid., 303.

${ }^{62}$ See Jane McIntosh Snyder, Lesbian Desire in the Lyrics of Sappho (New York: Columbia University Press, 1997) and Barbara Hughes Fowler, “The Archaic Aesthetic,” The American Journal of Philology 105, no. 2 (Summer, 1984): 119-49.

${ }^{63}$ Snyder, Lesbian Desire in the Lyrics of Sappho, 80 (see note above).

${ }^{64}$ Walker, Looking like What You Are, 47 (see note 47).

${ }^{65}$ Deborah Saville, "Dress and Culture in Greenwich Village," in Twentieth-Century American

Fashion, eds Linda Welters and Patricia A. Cunningham (Oxford: Berg Publishers, 2005), 53.

${ }^{66}$ Lady Diana Cooper qtd. in Guillermo de Osma, Fortuny: His Life and Work (New York: Skira Rizzoli, 2016), 129.

${ }^{67}$ Diana Collecott, H. D. and Sapphic Modernism (Cambridge: Cambridge University Press, 1999), 140.

${ }^{68}$ Benstock, Women of the Left Bank, 177 (see note 60). 
${ }^{69}$ See Martha Vicinus, Intimate Friends: Women who Loved Women, 1778-1928 (Chicago: Chicago University Press, 2004) and Leila Rupp, Sapphistries: A Global History of Love between Women (New York: New York University Press, 2011).

${ }^{70}$ Sandra M. Gilbert and Susan Gubar, "Female Female Impersonators: The Fictive Music of Edna St. Vincent Millay and Marianne Moore," in No Man's Land: The Place of the Woman Writer in the Twentieth Century, Volume 3: Letters from the Front, by Gilbert and Gubar (New Haven: Yale University Press, 1994), 57-120.

${ }^{71}$ Rebecca Ann Rugg, “How Does She Look?” in Femme: Feminists, Lesbians, and Bad Girls, eds Laura Harris and Elizabeth Crocker (New York: Routledge, 1997), 175.

${ }^{72}$ Maltry and Tucker, "Female Fem(me)ininities," 96 (see note 19). 